\title{
Occupational health aspects of the arsenic extractive industry in Britain (1868-1925)
}

\author{
M HARPER \\ From the TUC Centenary Institute of Occupational Health, London School of Hygiene and Tropical Medicine, \\ London WCIE 7HT, UK
}

\begin{abstract}
A historical survey into the occupational hazards of mining and refining arsenic is presented together with the measures adopted for their control. The industry is placed in the social perspective of its time and it is suggested that this experience could be of value to those who may encounter similar problems where arsenic is extracted elsewhere in the world.
\end{abstract}

Arsenic is most often found as the sulphide mineral arsenopyrite (FeAsS) intergrown with the ores of copper and sometimes with those of tin. Often the arsenopyrite has crystallised before the copper ores, giving a banded appearance to the veins. The association of tin, copper, and arsenic is common to the metallogenic province that includes Devon and Cornwall, Saxony and Bohemia, the Carpathians, and elsewhere in central and southern Europe.

\section{Hazards of mining}

By the sixteenth century the dangers of mining arsenical ores were well known even though the cause of the hazard was somewhat obscure. Traditionally, hard metallic ore veins were shattered by the application of fire. Specially shaped sticks were set against the rock face, ignited, and allowed to heat and crack the vein by differential expansion of the constituent minerals. When roasted, arsenopyrite produces arsenic oxide which will sublime into the atmosphere and condense on the cooler parts of the rock. It is readily soluble in the groundwater seeping through the mine to give a caustic solution. Arsenic oxide is extremely toxic through inhalation or skin adsorption, hence Agricola (1457):

"There is another illness even more destructive, which soon brings death to the men who work in those shafts or levels or tunnels in which the hard rock is broken by fire. Here the air is infected by poison ... which is driven out by the fire, and . . . is raised by the smoke. If this poison cannot escape from the ground, but falls down into the pools and floats on their surface, it often

Accepted 14 August 1987 causes great danger, for if at any time the water is disturbed ... these fumes rise again from the pools and thus overcome the men, by being drawn in with their breath; this is even much worse if the fumes of the fire have not yet all escaped. The bodies ... generally swell immediately and lose all movement and feeling, and they die without pain; men even in the act of climbing from shafts by the steps of ladders fall back into the shafts when the poison overtakes them, because their hands do not perform their office, and seem to them to be round and spherical, and likewise their feet."

These symptoms describe an acute intoxication by arsenic oxide, arsenopyrite being very common in the mines of Saxony. The chronic damage to lungs and eyes and the ulceration of feet and hands are also mentioned. The use of "respirators" (cloth veils) and leather boots and gloves is recommended and Agricola remarks on the prudence of miners who set fires late on Friday evenings to allow the fumes to clear before Monday.

Paracelsus also writes of the difference between chronic and acute arsenic poisoning, describing the characteristic chronic symptoms of pallor, thirst and gastrointestinal disturbances, and skin eruptions. In 1745 Henkel pointed out that poisonous materials ingested in small quantities from contaminated food may only show an effect after some longer period:

“... let a little poisonous ore enter your stomach every day for many years ... yet something will still remain attached, and will finally amount to so much, that one can have enough of it; and besides the intensity of arsenic is so rapid that it needs no long stay to poison flesh and blood. Or if one tries it ... one will be 
astonished by how much dust and ore usually collects on a narrow spot within six to eight hours. Indeed, I have sometimes wondered, whether the ore in the stomach is not worse than that in the lungs?"

Patissier, in 1822, also warns that workers in mines containing arsenic are imperilled by a chronic condition that includes moderate fever, leanness, colic, and weakness. ${ }^{2}$ It can therefore be seen that before the advent of a large scale arsenic extracting industry in south west England a body of information concerning the potential danger to miners was already in existence.

\section{Arsenic extraction in Britain}

Over much of south west England metal mining had been the basis of a local economy which boomed in the fourteenth century (silver) and in the sixteenth century (tin). The real heyday of the area began in 1800 and peaked between 1845 and 1865 when copper production from one mine, Devon Great Consols, outstripped all others. When the copper ore was nearly exhausted and the price of copper plummeted in the 1870 s it was a great relief to the mine directors that calcium arsenate had been discovered as an effective treatment for the cotton boll-weevil in the United States. Arsenic was also finding uses in the chemical, glass, and pigment industries. By 1870 fully half of the world's supply was being produced from this one mine. A large quantity of the arsenic ore, known locally as "mundic," had been left standing on the walls of the lode, up to five feet thick and containing up to $30 \%$ arsenic. ${ }^{3}$ Many of the mines situated along a short stretch of the River Tamar on the border of Devon and Cornwall were able to eke out a further 20 years of life on the proceeds of arsenic production. The four largest mines, Devon Great Consols, New Consols, Prince of Wales, and Gawton, each possessed their own refineries whereas produce of the smaller mines fed the giant Greenhill Arsenic Works.

By this period extraction of the ore involved mechanical drilling and blasting that would have liberated large quantities of the arsenic ore as dust. As table 1 shows, however, a combination of silica dust and radon was already dramatically reducing the life expectancy of drillers by silicosis and pulmonary neoplasm. What part may have been played by arsenic cannot be determined, especially in the absence of any postmortem observations due to the prejudices of the local population. It should be borne in mind, however, that arsenic has been implicated in lung cancer in other mining regions with highly arsenical ores. ${ }^{2}$

The portrait of an aging Cornubian miner as pallid and bronchitic is probably close to the truth. Miners at this time worked tribute pitches, auctioned to the highest bidder. Wages would fluctuate with mine conditions and the miner's capacity to work as well as with the quality of the lode. It is no wonder that as the price of copper and wages fell, a guaranteed wage above that of the average underground worker should attract men to the arsenic refining works. In fact attempts by the miners to get a guaranteed minimum had already led to the use of police constables and militia with the result that "blackleg" miners were drafted in from other parts of Cornwall. Many men were desperate for work when arsenic production was started.

The ore was washed and broken up to pass through a sieve. In this condition it would be suitable for roasting in air. The early Brunton calciner was a flat bed furnace kept revolving by a water wheel, which gradually stirred the ore. The later Oxland cylinder was a brick lined iron tube obliquely set and rotated to enable continuous roasting. From both types of furnace garlicky, yellow vapours were discharged through a series of regulating dampers into a series of two and a half feet thick masonry flues connected to a labyrinth of brick chambers where impure arsenic oxide "soot" was deposited. The residual vapours were passed over limestone screens and on through long flues to chimney stacks located on high ground which often contained a water cascade to further remove pollutants. Despite these precautions the emissions from these works did serious damage to the surrounding vegetation. Tin and copper could be recovered from the wastes from this operation.

The arsenic soot was further refined by roasting in flat furnaces using anthracite or coke. The product was known as white arsenic and it condensed on the tiled floors of a further series of brick lined chambers as white crystals of $99.5 \%$ pure arsenic oxide. This was removed by hand with shovels, ground between granite millstones, and packed into double lined sacks.

An output of 1000-2000 tons a year was maintained by Devon Great Consols until a few years before its final closure in 1902. Altogether nearly 73000 tons of refined arsenic oxide were sold which necessitated refining over 600000 tons of ore. The Greenhill

Table 1 Annual deaths from lung diseases in England and Wales (per 1000)

\begin{tabular}{llll}
\hline & \multicolumn{3}{l}{ Ages (years) } \\
\cline { 2 - 4 } & $15-34$ & $35-54$ & $55-75$ \\
\hline 1890-2: & $3 \cdot 7$ & $9 \cdot 6$ & $21 \cdot 6$ \\
All occupied men & $2 \cdot 9$ & $5 \cdot 6$ & $26 \cdot 5$ \\
Coal miners & $5 \cdot 0$ & $13 \cdot 4$ & $63 \cdot 7$ \\
Tin miners & & & \\
1900-2: & $3 \cdot 1$ & $33 \cdot 7$ & $72 \cdot 4$ \\
$\quad$ Tin miners & & \\
\hline
\end{tabular}


arsenic works continued operations from 1875 to 1925.

\section{Occupational health aspects of arsenic reduction}

Several possible occupations in this industry involved a risk of exposure to arsenious materials. Firstly, the grinders and millers were exposed to the dust of the sulphide ores. By virtue of its low solubility, arsenic in this form appeared to cause few problems. When grinding the finished product, however, the nostrils of the grinders were plugged with cotton wool and folded handkerchiefs were tied over their mouths to prevent accidental inhalation or ingestion. Fuller's earth was used to counteract the irritation caused by the eczema that appeared in the folds of the neck or around the nostrils.

The furnace operators or calciners complained of the effects of "smeech"- that is, the escape of gases containing arsenic and sulphur under certain wind conditions. This caused an extreme irritation of the respiratory tract if inhaled. They did not normally wear respiratory protection, however, as for most of the time it was not required.

The section of the workforce most at risk would have been those employed to shovel the arsenic oxide sublimate from the condensing flues and to package the final product. Local opposition to the burden on the poor rate caused by the possible ill health of these workers caused the Guardians of the Tavistock Union to commission a report from the Medical Officers of Health for Tavistock (Dr Brodick) and Calstock (Dr Bowhay). This report concluded that there was an excessive morbidity and mortality from lung disease and that this was due to the inadequacy of the respiratory protection. The impermeability of the lint and tightly folded handkerchiefs caused air to be drawn into the mouth from around the edge of the handkerchief so that it was not filtered and the men had occasion to complain that: “. . . after having been engaged in removing the arsenic soot from the flues, if the mouth is wiped out with a clean handkerchief a black deposit of soot is removed, and any expectoration is likewise tinged black".

The doctors go on to point out the "striking instance of cause and effect-the manufacture of a corrosive poison noted for its irritating effect on mucous membrane, a body of workmen whose air-passages are imperfectly protected from its effects, and a consequent disease and death-rate from respiratory disease among the workers out of all proportion to that of the general population."

The industry was thus brought to the attention of the Home Office and was made the subject of a joint inquiry by $\mathbf{H M}$ Deputy Inspector of Factories (Mr Gould) and HM Inspector of Mines (Mr Martin).
The Report on Certain Alleged Cases of Poisoning in Arsenic Reduction Works was completed in 1901 , although it never saw publication. These two gentlemen appear to have been rather antagonistic towards the medical men and criticised their report rather strongly. They did recognise that the commonest complaint consisted of the previously mentioned eruption around the folds and bends of the skin, particularly those areas most exposed such as the nose, mouth, and neck and also those portions of the body such as the armpits and genitalia where the arsenic oxide would be soluble in perspiration. Without treatment this would result in an extensive ulceration known as arsenic "pock" which involved great discomfort, ${ }^{4}$ and a scratch or slight abrasion of the skin would grow quickly into an ulcer that would only heal if the affected person remained away from the works for some time.

The report also recognised the greater seriousness of the bronchitis encountered in the industry, but the authors were inclined to attribute this to factors other than arsenic such as severe temperature fluctuations or to exposure to sulphur dioxide alone. The severity of the attacks, however, which began with a burning feeling in the throat and chest, the throat becoming dry, sore, and hoarse, finally leading to a copious expectoration after some days, was significantly greater than that which affected other metal smelters, even those engaged in producing sulphuric acid by roasting sulphide ores. It seems likely that arsenic was also implicated in this bronchitis. ${ }^{5}$

There is some suggestion that gastrointestinal disturbances including vomiting, abdominal cramp, and purging could have been sufficiently serious to warrant the removal of the affected person to his home in a cab. Other symptoms noted include conjunctivitis with oedema of the eyelids, peripheral neuritis manifesting itself as "pins and needles," and a brown pigmentation of the eyelids, temples, and neck. ${ }^{6}$ Apparently the most characteristic lesion was a perforation of the nasal septum, a condition about which most sufferers remained ignorant as, once produced there would have been no further discomfort.

The main criticism of the report appeared to be in regard to the local political wrangles concerning the burden of the affected workers and their dependants on the parish. It is true that the number of miners on the poor rate was rather higher and that their incidence of lung disease was rather similar (table 2). Since it was already known, however, that the miners of south west England were affected by an excessive rate of lung disease, the attempts by Messrs Gould and Martin to justify the level of illness among arsenic workers by a comparison with miners must be viewed with concern. In any event Doctors Brodick and Bowhay had also concluded that the arsenic workers were affected at an 
Table 2 Disablement as a result of lung disease among arsenic workers and miners in Calstock (1899)

\begin{tabular}{|c|c|c|c|c|c|c|c|}
\hline & \multirow{2}{*}{$\begin{array}{l}\text { Total No of } \\
\text { employees* }\end{array}$} & \multicolumn{5}{|c|}{ Age at disability } & \multirow{2}{*}{$\begin{array}{l}\text { Total } \\
\text { No of } \\
\text { disabled (\%) }\end{array}$} \\
\hline & & $20-29$ & $30-39$ & $40-49$ & $50-59$ & $\geqslant 60$ & \\
\hline $\begin{array}{l}\text { Arsenic workers } \\
\text { Miners }\end{array}$ & $\begin{array}{l}119 \\
210\end{array}$ & 4 & $\begin{array}{l}3 \\
4\end{array}$ & $\begin{array}{l}4 \\
4\end{array}$ & $\begin{array}{l}3 \\
7\end{array}$ & $\begin{array}{r}1 \\
12\end{array}$ & $\begin{array}{l}15(12 \cdot 6) \\
27(12 \cdot 9)\end{array}$ \\
\hline
\end{tabular}

*Including disabled.

earlier age. This suggestion was not addressed in the Home Office report.

Recommendations of the report included providing clean changing rooms and washing facilities, suitable overalls and clean underclothing, and appropriate respiratory protection. In addition restrictions were thought necessary over the temperatures at which cooling flues could be entered and the durations of the shifts worked in them. The principal concern was over the unhygienic practices of the workforce, especially with regard to cleanliness and the consumption of food.

It was decided that the arsenic works should not be subject to the same special rules governing the production of paints from lead and arsenic and that withdrawal of these rules could leave the way open to more appropriate voluntary or formal regulations. Both the sensitive nature of the industry and its subsequent economic collapse conspired to prevent this initiative.

\section{Conclusion}

The arsenic extraction industry was rather short lived in the United Kingdom. Reworking of mine waste dumps took place during the 1914-8 war, presumably to supply the manufacture of poison gas, and a further slight revival of mining occurred between 1923 and 1925. Production then ceased and the works now form part of the extensive industrial heritage of this country. It would have been of some interest if a follow up survey of the workers could have been possible. Unfortunately, the enormous depopulation of the area at this time would have involved trying to trace workers who had emigrated to many other countries. It is hoped that this review has come at an appropriate moment now that many countries in other parts of the world are stepping up production to meet the growing demands of the microelectronics industry.

\section{References}

1 Agricola G. De re metallica. Book VI. New York: Dover, 1950:215-6.

2 Rosen G. The history of miners' diseases. New York: Schuman's, 1943:121-3, 193.

3 Booker F. Industrial archaeology of the Tamar Valley. Newton Abbot: David and Charles, 1967:161-4.

4 Oliver T. Diseases of occupation. London: Methuen, 1908:217-8.

5 Arlidge JT. The hygiene, diseases and mortality of occupations. London: Perceval, 1892:432-3.

6 Legge TM. Arsenic poisoning. In: Kober GM, Hanson WC, eds. Diseases of occupation and vocational hygiene. Philadelphia: Blakiston's, 1916:5. 